\title{
Language, Power and Gender: A Case Study of Code Switching by Less Educated People In Pakistan
}

\author{
Asim KARIM \\ University of Management and Technology Lahore, Pakistan \\ asim.karim09@gmail.com \\ Safina KANWAL \\ University of management and Technolgy Lahore, Pakistan \\ safina_kanwal@yahoo.com
}

\begin{abstract}
The purpose of this study is to investigate the relation between language, power and gender among less educated people. Less educated people here mean those who passed only middle class examination. Foucault's theory of power and discourse gave new dimensions to languages. Language is used to exert power (Foucault, 1998). Due to this relationship of language and power, the speakers try to use that language as is enjoying power and high status in their speech community. Those of high status enjoying language is very much seen in the process of code switching where the speakers do code switching from low status enjoying language to high status enjoying language.

The major aims of this research were to find out the relation between language and power and how speakers' use of powerful language varied across gender. This study was quantitative. Data collection was done through questionnaire comprising of two sections. The first section was consisted of 10 close ended questions to know the relation between language and power. The second section of the questionnaire comprising of 10 close ended questions measured the status of Punjabi and Urdu. After careful inquires 30 less educated L1 Punjabi speakers were randomly selected from the city Sheikhupura. Among these 30 participants 15 were male and 15 were female. Audio recording was taken from 14 participants, 7 males and 7 females who had also took part in survey questionnaire to get the data about Urdu code switching. The results collected through the gathered data revealed the L1 Punjabi speakers regarded Urdu as powerful language and they asserted that language and power are closely related with each other. Further women used more powerful language and for this purpose they did more Urdu code switching as compared to men.
\end{abstract}

Keywords: power; discourse; multiculturalism; code switching

\section{Izvleček}

Namen te študije je raziskati povezavo med jezikom, močjo in spolom med manj izobraženimi ljudmi. Kategorija manj izobraženi se nanaša na tiste ljudi, ki imajo dokončano le srednješolsko izobrazbo. Foucaultova teorija moči in diskurza je v jezik vnesla nove razsežnosti. Foucaultu 
(1998) predstavlja jezik osnovni mehanizem moči. Zaradi povezave med jezikom in močjo skušajo govorci uporabljati tisti jezik, ki uživa v družbi največjo moč in ugled. Pogosto se dogaja, da govorci nižjih slojev uporabljajo jezik višjih slojev za menjavo kodov.

Ta raziskava si prizadeva najti povezavo med jezikom in močjo, nato želi ugotoviti, kako spol govorcev vpliva na uporabo jezika $\mathrm{z}$ večjo močjo. Raziskava je kvantitativne narave. Podatke smo zbrali na osnovi vprašalnika, ki je bil sestavljen iz dveh sklopov. Prvi sklop je obsegal 10 tesno povezanih vprašanj, katerih cilj je bil izluščiti povezavo med jezikom in močjo. Drugi sklop vprašalnika iz prav tako 10 tesno povezanih vprašanj je določil status pandžabščine in urdščine. Anketiranih je bilo 30 manj izobraženih govorcev pandžabščine (L1) iz mesta Sheikhupura. Polovica od njih je bilo moških in polovica žensk. Gradivo obsega še zvočne posnetke 14 anketirancev, od tega 7 moških in 7 žensk, ki so sodelovali tudi pri raziskavi o menjavi kodov v urdščini. Rezultati so pokazali, da so govorci pandžabščine (L1) mnenja, da je urdščina jezik moči. Raziskava je še pokazala, da so ženske uporabljale več jezika moči in pogosteje menjavale kode kot moški.

Ključne besede: moč; diskurz; večkulturnost; menjava kodov

\section{Introduction}

Michel Foucault, the French postmodernist, is despite being the most controversial thinker of the century (Phelan 1990) has been taken as a cultural icon (O'Farrel 2005: 1), massively leading in shaping the thinking of the present world about power and relations (O'Farrel 2005: 96-108). For him power is not just an instrument of intimidation used by the actors, rather 'power is everywhere' (Foucault, 1980, 1991). For Foucault power is not just an ability of exerting pressure rather power is a relation of elite and subjugation (19. Power is diffused and embodied in discourse, knowledge and 'regimes of truth' (Foucault 1991). For Foucault language exhibits power and power is exhibited through language. Power is transmitted and produced through discourse (Foucault 1998: 100). Discourse is a very slippery notion in Foucault's work. He says it is a certain 'way of speaking'. Language is used for this purpose of communication. So this relation between language and power is not simple rather it is very complex having various dimensions. That is why not all the languages enjoy equal status. Only some languages can 'evade, subvert or contest strategies of power' (Gaventa 2003: 3) and and discourse is a mode of transmitting power (Foucault: 1998, Rajchman 1983: 43). Thus speakers use language to exert power and to gain authority in society. This relation of language and power is very much seen in Pakistani society where all languages do not enjoy equal status. That is why the aim of the present study is to look into the relation between language and power. Further the present study was conducted to find out which language i.e. Punjabi or Urdu was powerful for L1 Punjabi speakers. The study also aimed to find out the relation between powerful language and the code switching for that language. The relation between gender and code switching for powerful language was also found out in the study. 
Pakistan is a multicultural and multilingual country where more than 72 languages are spoken (Ethnologue, 2009). But all these language do not enjoy equal status and power. Some languages are considered as prestigious languages while other languages are considered as inferior (Khalique 2006). Thus the relation between language and power is very much prevalent in Pakistan. The native speakers of less prestigious languages have also been loosing respect for their native variety. Due to this loss of respect and power on the part of some languages these languages are rapidly loosing their number of speakers. This shift from less powerful language is a great threat to these languages (Romaine 2007). So the present research was conducted to find out whether Punjabi, the mother tongue of Punjabians is on the verge of this threat or it is a safe language still having power and prestige. In this way in the perspective of multiculturalism, a postmodern movement where equal respect is given to all cultures and stress is laid on the homogeneous existence of all cultures, this shift towards certain language is also a threat to the very notion of multiculturalism.

Speakers use language to establish identity (Kim, Siong, Fei \& Ya'acob, 2010). That is why often speakers prefer to speak prestigious and powerful language(Riaz 2009). This attachment of power and prestige for certain language is also due to certain socio-political factors (Al-Tamimi\& Shuib 2009).Norton (2010) asserts that language should be understood not just as a "linguistic system, but as a social practice in which experiences are organized and identities are negotiated" (pp. 351).Nunan, D.\& Choi, J. (2010) also say that speakers use language for establishing identity and often speakers discard their relation with that language as is not enjoying prestige in their society though that language would be their mother tongue. In the present situation, it is the observation of the researchers that L1 Punjabi speakers break their linguistic ties with Punjabi as Punjabi is no more a prestigious language. It is often regarded as the language of illiterate and rustic people.

Code switching plays a significant role in breaking the ties with one language and establishing the linguistic ties with other language. Code switching is linguistic process in which the speaker switches from one code or language to another code or language (Migge 2007).This shifting from one code/language to another code/language can be at phrase level, word level and sentence level or beyond sentence level. Code switching is often done in the process of establishing linguistic identity. Yun (2008) and CarreraSabaté(2006) have closely examined the role of code-switching as a means of language socialization. In the present situation it was observed by the researcher that most of the L1 Punjabi speakers do code switching from Punjabi to Urdu. They do code switching for establishing their identity (Bhat 2008). 


\section{The research}

The present research was therefore conducted to find out the L1 Punjabi speakers' perception about the relation between language and power. Further L1 Punjabi speakers' perception about their own native language was found out through questionnaire. The research was also aimed to find out the status of Urdu for L1 Punjabi speakers. The relation between code switching and powerful language and gender was another core aim of the present research. It followed the descriptive and quantitative research methodology.

A survey and audio recording was conducted to ascertain the relationship between power and language and how less educated people in Pakistan cope with the reality. . The participants for language and power survey were selected by random sampling. The survey was done with the help of a questionnaire designed by the researcher. The present research had three variables that were gender, power and code switching for powerful language. Power was the independent variable of the first research question. For the third research question powerful language was the independent variable and code switching for the powerful language was the dependent variable. Gender was independent variable of the fourth research question and code switching for powerful language was the dependent variable of that research question.

\subsection{Sample}

The sample of the present study comprised of 30 L1 Urdu speakers whose education was middle and they knew how to read and write Urdu. All these participants were the class four workers of two colleges of Sheikhupura. One college was Government Degree College Sheikhupura and the other was Government Post Graduate College for Women Sheikhupura. These participants were selected through random stratified sampling. Among these participants 15 were female participants and 15 were male participants. The sample for audio recording was consisted of 7 females and 7 males. The equal number of male and female participant was kept to check the relation between gender and code switching for powerful language.

\subsection{Tools for data collection}

The present study used two tools to collect data. The first tool was a survey questionnaire and the second toll was audio recording.

\subsection{Questionnaire}

The questionnaire was comprised of two sections. Each section was consisted of 10 close ended questions. The first section of the questionnaire was designed to see the 
perception of the participants about the relation between language and power. The second section of close ended questions provided the quantitative data about the perception of L1 Punjabi speakers about their mother tongue and also about Urdu. The close ended questions of this section were having two options: one was Punjabi and the second was Urdu. The survey questionnaire was also comprised of two open ended questions. These questions asked the participants' view about the relation between language and power. This data was qualitative.

\subsection{Audio Recording}

Audio recording was taken of 14 participants to find out the number of Urdu code switched items. This audio recorded data was collected from the workers of two institutions i.e. GPW and GC. The total number of participants for the audio recorded data was 14 . Among those 14 participants 7 were male participants and 7 were female participants. The reason behind the equal number of male and female participants was to find out the relation between gender and Urdu code switching. The time given to each participant was 5 to 7 minutes. The participants randomly selected. The topics given to them for discussion were from everyday life so that the researcher could get maximum natural data. The selected participants for audio recording data had also taken part in the survey questionnaire.

\subsection{Data Collection Procedures}

For the collection of data the researcher went to the two selected colleges of Sheikhupura. These three colleges were Government Post Graduate College for Women Sheikhupura (GPW) and Government Degree College Sheikhupura. Fifteen participants from each college were randomly selected whose mother tongue was Punjabi. These participants were first given survey questionnaire and they all were having just middle i.e. $8^{\text {th }}$ class education. For keeping the equal representation of male and female, 15 female participants were selected from GPW as it was a female college, 15 male participants from GC as it was a male college. All the steps of data collection were taken while keeping in mind all the variables of the research. The researcher also kept in mind the sanctity of research in her mind while conducting research. During the audio recorded session maximum effort was taken by the researcher to make the interest of the participants alive in discussion. They were given with this confidence that their background information would be kept confidential. Further the topic given to the participants were also chosen by taking the consent of the participants. Individual interviews were conducted and the reason behind individual interview was to look into the individual level of code switching. 


\section{Results}

\subsection{Survey Questionnaire Results}

The survey of the present was consisted of three sub sections. The first section of the survey questionnaire was designed to know about the perception of the participants about the relation between language and power. The statement was, 'Language is power'. Among the 30 participants 25 participants answered that language is power, 5 participants ticked "no" for that statement.

The second statement of the first section of the survey was 'language does not give prestige to its speakers'. 28 participants rejected that statement and 2 participants agreed with that statement. The third statement of the survey was that language gives authority to its speakers. For this statement 27 participants ticked the yes option where as 3 participants ticked no option. 'Languages are not good or bad' was the fourth statement of the first section of the questionnaire. Among the 30 participants 4 participants chose the yes option whereas 26 participants chose the no option. Statement 6 asked the participants that good language gives respect to its speakers. 28 participants agreed that good language gives respect to its speakers. The next statement of the first section was 'Use of language does not make difference'. 2 participants were agreed with this statement while the rest of 28 participants disagreed with this statement. All the 30 participants were agreed with that 'good language should be used by the speakers' which was the $7^{\text {th }}$ statement. 'Language cannot make good impression' was the next statement of the first part of the questionnaire. 26 participants ticked yes option for that statement and 4 participants ticked the no option for that statement. The second last statement of the first part was 'some languages are powerful and some languages are powerless'. All the participants were agreed that some languages are powerful and some languages are powerless. 'A person must use powerful language' was the last statement of the first section of the questionnaire. All the participants ticked yes answer for that statement.

The section 2 of the questionnaire was designed to know which language was powerful for the L1 Punjabi participants. This section was comprised of 10 questions. The participants were provided with two options. One option was Punjabi and the second option was Urdu. The first question of the $2^{\text {nd }}$ section asked the participants about the language they speak. 12 participants chose the option for Punjabi and 18 participants chose the option for Urdu. The second question asked the participants about the best language. The second question asked the participants about the best language. 5 participants considered Punjabi as the best language whereas 25 participants considered Urdu as the best language. The next question asked the participants about the language that does not give respect to its speakers. Among the 30 participants 26 participants ticked Punjabi as a language that does not give respect to 
its speakers and 4 participants ticked Urdu as a language that does not give respect to its speaker. 'Which is the inferior language' was the fourth question. 28 participants marked Punjabi as the inferior language and 2 participants regarded Urdu as the inferior language. Fifth question of the second section asked the participants about the powerful language. 3 participants were of the opinion that Punjabi is a powerful language and 27 participants thought that Urdu is powerful language. 'Which should be our national language' was the sixth question of the second section of the questionnaire. Punjabi should be our national language in the opinion of 2 participants and Urdu should remain our national language in the perception of 28 participants. The next question inquired the participants about the language that is an obstacle in the way of success of participants. Among the 30 participants 27 considered Punjabi as an obstacle in their way of success and 3 participants considered Urdu as an obstacle in their way of success. 'Which language gives high status to its speaker' was the eighth question of the second section. Only 1 participant marked Punjabi as a language that gives high status to its speakers while the rest of all participants marked Urdu as a language that gives high status to its speakers. Ninth question asked the participants about the powerless language. Punjabi is a powerless language for 27 participants while Urdu is powerless language for 3 participants. The last question of the second section of the questionnaire was about the language that participants use for making their good impression. Only two participants marked Punjabi for this question and 28 participants marked Urdu for this question.

\subsection{Audio Recorded Data}

F1 was the first female participant. She was a woman of 32 years. The first question asked to her was 'What do you do in your spare time'. The answer given by F1 for this question was of 317 words. Among these 317 words of Punjabi, 39 words were from Urdu. The next question F1 was 'Do you like your job'. Her answer was consisted of 345 words and out of those 345 words 55 words of Urdu. The next participant was F2 and she was a young girl of 24 years. The question asked to her was in Punjabi and the question is 'Which TV programs do you watch'. Her answer for this question was consisted of 343 words. F2 used 32 words from Urdu. She did code switching at sentence level as well as at intra - sentential level. The next question to F2 was in Punjabi and Urdu and the question was 'who is your favourite actor and why'. The answer of this question given by F2 was consisted of 310 words and out of those 310 words 26 words were in Urdu. The third participant for the audio recorded data was F3 who was a woman of 35. The first question asked to her was in Punjabi and it was 'Do you like to go to bazaar and where do you go for shopping'. The answer of F3 for this question was consisted of 279 words and out of these 279 words 41 words were of Urdu. The next question asked to her was 'Do you do window shopping'. Her 
answer for that question was of 445 words and out of those 445 words 65 were of Urdu.

F4 is the fourth female participant for audio recorded data. The first question asked was 'which is your favorite food and why'. The answer given by F4 was based on 362 words. Out of these 362 words 53 words were of Urdu. She did code switching at word level. The second question asked to F4 was in Urdu and Punjabi exhibiting the phenomenon of code switching from Punjabi to Urdu and the question was 'What is the role of a mother'. The answer given by F4 for this question was comprised of 302 words and out of these 302 words 25 were of Urdu. The question to next female participant i.e. F5 was in Urdu and the question was 'Why women love to go to beauty salon'. The answer for this question given by F5 was of 355 words and out of 355 words 56 words were of Urdu. The second question to F5 was in Urdu and Punjabi and the question was 'which is your favorite season and why'. Her answer for that question comprised of 292 words in total and 27 words of Urdu. The next female participant was F6. She was a lady of 39. The question asked to her was in Punjabi and the question was 'Do you think that dowry should be given to a girl'. Her answer for this question was of 509 words and she took 6 minutes to answer the question so only one question was asked to her. Out of those 509 words 55 words were from of Urdu. The last female participant was F7 and the question asked to her was 'Who was your film actor and why'. The answer was consisted of 410 words and out of those 410 words 55 words were of Urdu. The question asked to her was in Punjabi and the question was 'What is the nature of your job'. The answer given by her was comprised of 202 words and out of those 202 words 25 were of Urdu.

M1 was the first participant for audio recording. The first question asked to him was in Punjabi and the question was 'Which is your favorite city and why'. The answer given by M1 was 355 words and out of those 355 words 50 words were of Urdu. The next question asked to him was 'Which is your favorite actress and why'. The answer for that question was of 310 words and out of these 310 words 31 words were of Urdu. M2 was the next participant and the first question asked to him was 'Who is your favorite cricketer and why'. His answer for that question was of 333 words and out of those 333 words 45 words were of Urdu. The next question asked to him 'What is the role of a father'. The answer by M2 for that question was of 278 words and out of those 278 words 22 words were of Urdu. The first question asked to M3 was 'Are you satisfied with your job'. The answer for this question by M3 was of 410 words and out of those 410 words 59 words were of Urdu. The second question asked to him was 'What is the role of a mother' and his answer was consisted of 210 words and out of those 210 words 27 words were of Urdu. The next participant was M4 and the question to him was 'What is the role of education in personality development'. M4 answer for that question was of 610 words and out of those 610 words 49 were of Urdu. 
M5 was the fifth participant and the first question asked to him was 'Which is the most unforgettable incident of your life'. His answer for that question was of 398 words and out 398 words he used on 9 words of Urdu. The next question to him was in Urdu and the question was 'Who is your hero in history'. The answer for that question was of 330 words and out of those 330 words only 5 words were of Urdu. M6 was the next participant. The question to him was 'What will you do if you become the principal of the college'. His answer was of 276 words and he had not used a single word of Urdu. The next question to him was 'Are you satisfied with Pakistani politicians'. The answer of M6 for that question comprised of 410 words and he used only 7 words of Urdu in 410 words. M7 was the last male participant for audio recording. The question asked to him was both in Urdu and Punjabi and the question was 'What are your good qualities'. The answer given by him consisted of 299 words and out of these 299 words, 16 words were from Urdu. He has code switched at word and phrase level only. The next question to him was in Urdu and the question was 'Are you in favor of liberty of women'. His answer was of 388 words and out of 388 words, 21 words were of Urdu.

\section{Discussion and interpretation of Results}

The following discussion on results is based on the results of table 1 given below. This table is about the females' result of first section of the survey. $83 \%$ of the participants agreed that language is power. Thus majority of the participants regarded language as power. $93 \%$ of the participants did not agree that all languages did not give prestige to its speakers. So there is a close relation between language and prestige. Language gives authority to its speaker in the opinion of $90 \%$ of the participants. $87 \%$ of the sample did not agree that languages are not good and bad. Most of the participants i.e. 93\% were of the view that good language gives respect to its speakers. $93 \%$ of the participants disagreed that language use makes no difference. 1005 of the population agreed that good language should be used. 
Table 1: Results of Power and Language Section of Survey

\begin{tabular}{|l|c|c|c|c||}
\hline Theme of question & Yes & No & $\begin{array}{c}\text { Percent. } \\
\text { for yes }\end{array}$ & $\begin{array}{c}\text { Percent. } \\
\text { for no }\end{array}$ \\
\hline Language is power & 25 & 5 & $83 \%$ & $17 \%$ \\
\hline Language does not give prestige & 2 & 28 & $7 \%$ & $93 \%$ \\
\hline Language gives authority & 27 & 3 & $90 \%$ & $10 \%$ \\
\hline Languages are not good and bad & 4 & 26 & $13 \%$ & $87 \%$ \\
\hline Good language gives respect & 28 & 2 & $93 \%$ & $7 \%$ \\
\hline Language use makes no difference & 2 & 28 & $7 \%$ & $93 \%$ \\
\hline Good language should be used & 30 & 0 & $100 \%$ & $0 \%$ \\
\hline Language cannot make good impression & 4 & 26 & $13 \%$ & $87 \%$ \\
\hline Languages are powerful and powerless & 30 & 0 & $100 \%$ & $0 \%$ \\
\hline Powerful language should be used & 30 & 0 & $100 \%$ & $0 \%$ \\
\hline
\end{tabular}

Most of the participants did not agree that language cannot make good impression. $100 \%$ of the participants of the sample agreed that some languages are powerful while other languages are powerless and powerful language should be used. The results of the first part of the questionnaire show that there is a close relation between language and power as is asserted by Foucault (1998). People exert power through language in the opinion of the participants as $90 \%$ of the participants were of the view that language gives authority to its speakers.

The table 2 provides the answer for the second research question i.e. which is the powerful language for L1 Punjabi speakers. Large no. of the participants said that they speak Urdu as it is the 'best language' as reported by $83 \%$ of the participants. Punjabi is a language that 'does not give respect to its speakers' in the opinion of $87 \%$ of the participants. Further Punjabi is an inferior language as a vast majority i.e. 93\% of the participants ranked it as inferior language. Language and power are closely related and that is why $90 \%$ of the population regarded Urdu as a powerful language. Urdu should remain the national language of Pakistan in the opinion of $93 \%$ of the participants. Most of the participants i.e. 90\% regarded Punjabi as an obstacle in their way of success. Urdu is a 'high status giving language' reported by $97 \%$ of the population. Punjabi is a 'powerless language' in the opinion of $90 \%$ of the L1 Punjabi speakers. This shows that Punjabi has lost its worth even for its native speakers. $93 \%$ of the participants agreed that Urdu is a language that they use for making their good impression on others. 
Table 2: Results of Section 2

\begin{tabular}{|l|c|c|c|c|}
\hline Theme of question & Punjabi & Urdu & $\begin{array}{c}\text { Perc. for } \\
\text { Punjabi }\end{array}$ & $\begin{array}{c}\text { Perc. for } \\
\text { Urdu }\end{array}$ \\
\hline Language participant speak & 12 & 18 & $40 \%$ & $60 \%$ \\
\hline Best Language & 5 & 25 & $17 \%$ & $83 \%$ \\
\hline Language does not give respect & 26 & 4 & $87 \%$ & $13 \%$ \\
\hline Inferior Language & 28 & 2 & $93 \%$ & $7 \%$ \\
\hline Powerful Language & 3 & 27 & $10 \%$ & $90 \%$ \\
\hline National Language & 2 & 28 & $7 \%$ & $93 \%$ \\
\hline Language that is obstacle & 27 & 3 & $90 \%$ & $10 \%$ \\
\hline High Status Giving Language & 1 & 29 & $3 \%$ & $97 \%$ \\
\hline Powerless Language & 27 & 3 & $90 \%$ & $10 \%$ \\
\hline Language that gives Good Impression & 2 & 28 & $7 \%$ & $93 \%$ \\
\hline
\end{tabular}

Thus the results of the second section of the questionnaire reveal that Punjabi is a powerless language for most i.e. $90 \%$ of the L1 Punjabi speakers and Urdu is a powerful language for most of i.e. $90 \%$ of the population. Further Punjabi has become an inferior language even for its own native speakers as most of i.e. 93\% of L1 Punjabi speakers regarded it as inferior language when compared with Urdu. The results of this section provide the answer of the second research question that Urdu is the powerful language for L1 Punjabi speakers.

The results of the audio recorded data show that L1 Punjabi speakers did code switching for prestigious and powerful language i.e. Urdu. All the participants did Urdu code switching for Urdu. The code switching for Urdu was done at word, phrase, sentence and intra-sentential level. It shows that Urdu has got its deep roots in Punjabi speakers. It has become the part and parcel of the everyday discussion of the L1 Punjabi speakers. Further the participants did not consciously did code switching rather they unconsciously did code switching as it is found at all levels. The following two tables table 3 and table 4 are showing the total number of words spoken by each participant in audio recording and the total number of Urdu code switched items done by each participant. The tables are also showing the percentage of Urdu code switched items done by each participant. The results of the Urdu code switched items prove that L1 Punjabi speakers did code switching from a powerless language i.e. Punjabi to a powerful language i.e. Urdu. This they did to gain respect, high status, prestige and power as all of the participants of the survey questionnaire agreed that powerful and 
prestigious language should be used by the speakers as powerful language bestows honour and high status to its speakers.

Table 3: Female Results for Urdu Code Switching

\begin{tabular}{|l|c|c|c||}
\hline $\begin{array}{l}\text { Fake name of } \\
\text { female } \\
\text { participants }\end{array}$ & $\begin{array}{c}\text { Total no. of words } \\
\text { spoken by } \\
\text { participant }\end{array}$ & $\begin{array}{c}\text { No. of Urdu code } \\
\text { switched items }\end{array}$ & $\begin{array}{c}\text { Percentage for } \\
\text { Urdu code } \\
\text { switching }\end{array}$ \\
\hline \hline F1 & 662 & 94 & $14 \%$ \\
\hline F2 & 653 & 58 & $9 \%$ \\
\hline F3 & 742 & 106 & $14 \%$ \\
\hline F4 & 664 & 78 & $12 \%$ \\
\hline F5 & 647 & 83 & $13 \%$ \\
\hline F6 & 509 & 55 & $11 \%$ \\
\hline F7 & 612 & 80 & $13 \%$ \\
\hline
\end{tabular}

Table 4: Male Results for Urdu Code Switching

\begin{tabular}{|l|c|c|c||}
\hline $\begin{array}{l}\text { Fake names of } \\
\text { male participants }\end{array}$ & $\begin{array}{c}\text { Total no. of words } \\
\text { spoken by } \\
\text { participant }\end{array}$ & $\begin{array}{c}\text { No. of Urdu code } \\
\text { switched items }\end{array}$ & $\begin{array}{c}\text { Percentage for } \\
\text { Urdu code } \\
\text { switching }\end{array}$ \\
\hline \hline M1 & 665 & 81 & $12 \%$ \\
\hline M2 & 611 & 67 & $11 \%$ \\
\hline M3 & 620 & 86 & $14 \%$ \\
\hline M4 & 610 & 49 & $8 \%$ \\
\hline M5 & 728 & 14 & $2 \%$ \\
\hline M6 & 686 & 7 & $6 \%$ \\
\hline M7 & 687 & 37 & \\
\hline
\end{tabular}

The comparative results of male and female participants for Urdu code switching reveal that as compared to L1 male Punjabi speakers L1 female Punjabi speakers did more code switching for Urdu. This shows that women are more inclined towards the use of powerful and prestigious language as compared to men. They want to assert their identity through prestigious language. 
Table 5: Comparative Results of Section 1 for Males and Females

\begin{tabular}{|lccc||}
\hline $\begin{array}{l}\text { Fake male } \\
\text { participants } \\
\text { names }\end{array}$ & $\begin{array}{c}\text { Urdu code } \\
\text { switched items } \\
\text { percentage }\end{array}$ & $\begin{array}{c}\text { Fake male } \\
\text { participants } \\
\text { names }\end{array}$ & $\begin{array}{c}\text { Urdu code } \\
\text { switched items } \\
\text { percentage }\end{array}$ \\
\hline \hline M1 & $12 \%$ & F1 & $14 \%$ \\
M2 & $11 \%$ & F2 & $9 \%$ \\
M3 & $14 \%$ & F3 & $14 \%$ \\
M4 & $8 \%$ & F4 & $12 \%$ \\
M5 & $2 \%$ & F5 & $13 \%$ \\
M6 & $1 \%$ & F6 & $11 \%$ \\
M7 & $6 \%$ & F7 & $13 \%$ \\
\hline \hline
\end{tabular}

\section{Conclusion}

From the above discussion on the results collected through questionnaire and audio recorded data, it becomes very clear that language and power are correlated with each other. It is the attribution of power that gives status to language and also to its speakers. In Pakistan for L1 Punjabi speakers Punjabi is not a powerful language. It is considered as inferior and powerless language. Urdu is regarded as powerful language as powerful language as it gives prestige, high status and respect to its speakers. That is why most i.e. $60 \%$ of the L1 Punjabi speakers prefer to speak Urdu. They want to establish their identity through Urdu and not through their mother tongue. This is the reason in their every day conversation the code switch for Urdu. It is very serious situation as this preference for one language has become a threat for another language and the culture that is associated with this language. Punjabi language as well as Punjabi culture they on the very of linguistic genocide and culture death. So we, being researchers and government of Pakistan should pay attention towards this very serious issue.

\section{Recommendations}

The present study has brought so many areas in which research can be done in future. For example research can be done on the status of other regional languages of Pakistan. It will help us in knowing about the status of other regional languages. Further the present research was carried out on less educated people. Future research can be carried on illiterate people to know their perception about language and power and also about the powerful language. There is need of carrying research in villages as most of our population still lives in villages and that research give provide the 
views of most of the people. Moreover villages are still having strong culture and this research will through light on the relation between culture and language.

\section{References}

Al-Tamimi, A. \& Shuib, M. (2009). Motivation and attitudes towards learning English: A study of Petroleum Engineering undergraduates at Hadhramout University of Science and Technology. GEMA Online Journal ofLanguage Studies, 9 (2), 29-55.

Bhatt, R. M. (2008). In other words: Language mixing, identity representation and third space. Sociolinguistics, 177-200.

Carrera-Sabaté, J. (2006). Some connections between linguistic change and the written language: The behavior of speakers aged 3 to 20. Language Variation and Change 18:1534.

Eckert, P. \& McConnell-Ginet, S. (2003).Language and Gender. New York: Cambridge University Press.

Fairclough, N. (1989). Language and Power. London: Longman.

Foucault, M. (1991). Discipline and Punish: the birth of a prison. London, Penguin.

Foucault, M. (1998). The History of Sexuality: The Will to Knowledge. London, Penguin.

Foucault, M. 1980. "truth and Power”. Trans. Colin Gordon. In Power/Knowledge. New York : Pantheon Books,

Gaventa, J. (2003). Power after Lukes: a review of the literature. Brighton: Institute of Development Studies.

Khalique, H. (2006). The Urdu English relationship and its impact on Pakistan's social development. International Wissenschaftsforum Heidelberg International Workshop. Heidelberg.

Kim, L.S.; Siong, L.K.; Fei, W. F. \& Ya'acob, A. (2010). The English language and its impact on identities of multilingual Malaysian undergraduates. GEMA Online Journal of Language Studies, 10 (1), 87-101.

Migge, B. (2007). Code-switching and Social Identities in the Eastern Maroon Community of Suriname and French Guiana. Journal of Sociolinguistics, 11/1, 2007: 53-73.

Norton, B. (2010). Language and identity. In N. H. Hornberger \& S. L. McKay (Eds.), Sociolinguistics and language education (pp. 349-369). Bristol: Multilingual Matters.

Nunan, D., \& Choi, J. (2010). Language, culture and identity: Framing the issues. In D. Nunan \&A. Choi (Eds.), Language and culture: Reflective narrative and the emergence of identity (pp. 1-13). New York: Routledge.

O'Farrel, C. (2005). Michel Foucault. Sage.

Phelan, S. Foucault and Feminism in American Journal of Poltical Science. Vol 34. No 2. Pp 421-440. Stable URL: http://www.Jstor.org/stable2111456. . Accessed12/04/2013.

Rajchman, J.1983. "Foucault and the Ends of Modernism"in October. Vol 24, pp37-62. Stable URL: http://www.Jstor.org/stable 778592. Accessed 28/3/2013.

Riaz, S. (2009). Exploration of the Socio-cultural, Linguistic and Psychological Factors involved in Intrasentential Code-switching from Urdu to English. Unpublished M.Phil thesis. Department of AIS, National University of Modern Languages, Islamabad. 
Romaine, S. (2007): Preserving Endangered Languages. In: Language and Linguistics Compass 1 (1-2), 115-132.

Sunderland, J. (2004). Gendered Discourse. New York: Palgrave Macmillan.

Yun, S. (2008). Role-play and language socialization among bilingual Korean children in the United States. Simulation and Gaming, 39(2), 240-252. 
